\title{
Aspekte van 'n Islamitiese Renaissance
}

\author{
D J C van Wyk
}

Die werklike verhouding van Islam en die Christendom is vandag in baie opsigte ' $n$ verwarrende aangeleentheid. Dit blyk byvoorbeeld daaruit dat sommige geleerdes beweer dat Islam homself vandag hardnekkiger as ooit tevore teen die Christelike kerk en geloof verset. Ander sien weer in huidige ontwikkelinge dié groot geleentheid vir die Christelike kerk en sending.

Geleerdes soos $\mathrm{H}$ Belloc het reeds in die dertigerjare van hierdie eeu voorspel dat daar' $n$ nuwe oorlog tussen Islam en die Christelike Weste op pad is. Die resente rewolusie of reformasies in Iran, Afghanistan en Pakistan het onteenseglik bewys dat baie Moslems ryp en gretig is daarvoor om terug te keer tot die oorspronklike vorm van hul geloof. Of die intensiteit van godsdienstige emosie wat hier skuilgaan in ons Westerse wêreld goed genoeg besef en begryp word, is inderdaad 'n ernstige vraag.

Dat die Arabiese wêreld, afgesien van alle ander oorwegings, veel inhou wat fassinerend is, is nie te betwyfel nie. Die hele MiddeOosterse wêreld is al beskryf as 'n land gevul met dromers en gebede. Dis die wêreld van Cyrus, eerste groot koning van die Persiese Ryk en bevryder van Israel van Babiloniese oorheersing. Dis ook die land van die wyse manne uit die Ooste, die Shah van Iran en die Ajatollah Khomeini; ' $n$ man met die droom van 'n Islamitiese Republiek op die patroon van Mohammed se teokrasie 1300 jaar gelede. Dis 'n land met 'n komplekse mosaïek van mense, godsdienste en politieke sisteme.

Drie groot wêreldgodsdienste het menslik gesproke hulle oorsprong hier 'n klipgooi van mekaar af gehad, naamlik Judaïsme, Christendom en Islam. Al drie is tot vandag toe intens betrokke rondom die stad Jerusalem.

Dit is nodig om in die oorweging van die huidige opkoms van Islam, die groot lyne uit die geskiedenis in gedagte te hou. Hierdie geskiedenis vertoon 'n lang ketting van aksie en reaksie van Weste en Islam op mekaar. Gedurende die eerste eeue van sy bestaan het Islam dwarsoor die destydse Christelike wêreld uitgebrei. Dit kan, benewens ander faktore, ook toegeskryf word aan die onvermoë van die kerk en die evangelie om in sy vroeë bloeitydperk die Arabiese wêreld te bereik. As antwoord op die Islamitiese ekspansie het die kruistogte gevolg. Op sy beurt het die Islam op die kruistogte geantwoord met die reveil van 'n meer konserwatiewe vorm van Islam. 
Nadat die Islam aan die moeë middeleeuse Christendom 'n sterk bestuiwing vanuit die Griekse erfenisse toegedien het, is hy self mettertyd deur die opkomende Westerse oorheersing teruggedring tot 'n toestand van minderwaardigheid en onderwerping.

Vandag herhaal die geskiedenis homself. Voorlopig kan ons sê dat die kragtige wyse waarop Islam tans besig is om op die Westerse prestasie te antwoord en hom aan dié toestand van minderwaardigheid te ontworstel met die volgende faktore verband hou: die Arabiese bedingingsmag op grond van sy olierykdomme; 'n aggressiewe verset teen eeue se Westerse meerderwaardigheid wat hy moes sluk; en helaas - die konstante mislukking van die kerk om hierdie wêrelddeel met die evangelie van Jesus Christus te bereik.

As vandag gepraat word van 'n Renaissance van Islam moet onthou word dat dit op geen wyse 'n verligte, liberale, moderne beweging is nie. Daar moet besef word dat ons hier te doen het met die herlewing van 'n konserwatiewe, fundamentalistiese Islam, 'n terugkeer na die fanatisme van die Middeleeue.

Ons sou ook kon praat van 'n kulturele rewolusie in Islam vandag waarmee gereageer word op 'n neokoloniale imperialisme uit die Weste wat meer ekonomies as polities bepaal is. Daar word kragtig opgekom vir 'n Islamitiese identiteit wat homself bedreig voel deur Westerse waardes.

\section{Kort tipering van Islam}

Om 'n kort en bondige tipering van Islam as godsdiens en kultuurverskynsel te gee, is geen maklike taak nie. Enersyds word graag gesê dat Islam 'n eenvoudige pligtegodsdiens is wat reglynige antwoorde selfs op moderne vrae bied. Terselfdertyd is sowel die Arabiese taal as die Koran so moeilik dat baie min mense hulle werklik daarin verdiep. Enersyds word graag gesê Islam is 'n konserwatiewe, fundamentalistiese en Middeleeuse verskynsel wat hom nie in die moderne wêreld kan aanpas of handhaaf nie. Andersyds is daar onrus oor 'n magtige, opdringende herlewing van Islam. Hoe dit ook al mag wees, Islam beskik oor die vermoë om van sy aanhangers felle, fanatiese en verknogte volgelinge van Allah te maak.

Dit kan nie anders as om verwondering te wek nie: 'n Volk, naamlik die Arabiere, wat in die kernlande van die ou beskawing waar die wêreldgeskiedenis 'n aanvang neem, vir 'n tyd lank 'n geweldige rol speel, dan vir byna 1000 jaar stagneer, om tans weer met nuwe saamhorigheidsgevoel na bo te beur om sy plek tussen die wêreldgodsdienste in te neem.

Ook dit moet verwondering wek: Islam wat as godsdiens onder die Arabiere ontstaan, hierdie grens mettertyd egter so oorskry dat 
vandag slegs een vyfde deel van die totale aantal Moslems op die aarde nog Arabiere is.

Die leer van Islam is in een woord, een naam saamgevat: Allah. Die almag en eenheid van Allah en die naderende gerig; dit loop soos 'n skerp rooi lyn dwarsdeur die Koran. Vyf keer per dag weerklink die dwingende appèl van die gebedsroeper: "Allah is die grootste. Ek getuig daar is geen God nie behalwe Allah. Mohammed is die apostel van Allah. Kom tot die gebed." Die geloof in die almag van Allah, vervul met gepaardgaande gevoelens van nasionalisme, bring gloeiende geloofsywer mee en kweek felle, verknogte aanhangers.

Die Moslem spreek die naam van Allah honderde keer per dag uit. Waar die Jood God eer deur sy Naam nie uit te spreek nie, vereer die Moslem Allah deur sy naam soveel moontlik uit te spreek.

Geloof is vir die Moslem oorgawe aan Allah en die aanvaarding as waar van alles wat Allah deur die Koran sê. Uit die staanspoor is in die Islam fel gestry teen enige vorm van politeïsme. Daarby ken die Moslem nie so iets soos 'n persoonlike, intieme verhouding met Allah nie. Allah het die goeie mens lief. Die sondaar het hy nie lief nie.

Die belydenis dat Mohammed die seël van die profete is, speel ' $n$ geweldige rol onder die Moslems. Mohammed is die laaste profeet voor die oordeelsdag aanbreek. In die tradisie van die profete is hy die heel laaste. Enige gedagte egter dat Mohammed aanbid moet word as God of dat hy bonatuurlik is, word deur die Moslem fel verwerp. Hy neem hoegenaamd nie die plek by Islam in wat Christus in die Bybel inneem nie. Die plek wat Jesus in die Christendom inneem, word in Islam deur die Koran ingeneem.

Mohammed is volgens Islam gestuur tot die Arabiere, die enigste volk wat nog geen waarskuwer gekry het nie. Nou het elke volk'n billike kans gekry. Nou volg die groot eindbeslissing. Selfs die Mahdi, die kalief wat sal verskyn kort voor die aanbreek van die oordeelsdag, sal niks toevoeg by die openbaring wat deur Mohammed afgesluit is nie.

Die verskil tussen Mohammed en alle vroeëre profete is selfs daarin geleë dat hy 'n Arabier is, gestuur tot 'n volk aan wie die ou boodskap nog nooit bekendgemaak is nie. Die Christendom in Arabië het tot op die tyd van Mohammed weinig aan sendingywer geopenbaar. In hierdie vakuum tree Mohammed op as aspostel van die Arabiere. Dit kan so gestel word: Islam het in Arabië 'n vakuum gevul tussen 'n heidendom wat reeds in sy fondamente geskok was en in 'n sosiale krisis verkeer het en andersyds 'n nog verwarde invloed vanuit die Christendom wat hom reeds aanmeld, maar nog geen oproep vir Arabië verwoord het nie. Of: die Christendom het eensydig in Hellenistiese rigting uitgebrei. Daardeur en deur die 
swakheid van die Jode-Christendom is 'n vakuum gelaat wat deur Islam gevul sou word.

Vir die Moslem is Jodedom en Christendom dus ou oorwonne standpunte wat tans loon vir hul dade ontvang. Enige suggestie om Christen te word, is vir die Moslem ' $n$ terugwaartse stap en ' $n$ belediging.

Die sending van Mohammed strek hom uit tot alle volke. Van die mees kenmerkende eienskappe in Islam is die eenheid en broederskap, asook die krag van hierdie godsdiens onder sy aanhangers.

Koran beteken voordrag, resitasie. Die Koran bevat die bonatuurlike diktaat van Allah aan Mohammed. Vanweë die sentrale plek wat die Koran in die Islam inneem, word van Islam gepraat as godsdiens met 'n boek. Koran is die Ipissima Verba, die presiese eie woorde van Allah self. Die Moslem glo dat soos die Ou Testament deur die Nuwe vervul is, so is die Nuwe Testament deur die Koran vervul.

Die pligteleer van Islam bestaan uit die volgende:

- die uitspreek van die geloofsbelydenis;

- die verrigting van die salát, die rituele gebed;

- die onderhouding van vastye;

- beoefening van weldadigheid;

- die verrigting van die seremonies.

Om tot die gemeente van die profeet te behoort - dit is wat alle Moslems met mekaar in gemeen het. En om tot hierdie gemeenskap te behoort, dit vorm 'n waarborg vir hierdie lewe en daarna. Tot hierdie gemeenskap behoort elkeen wat hom aan die wil van Allah onderwerp. Alle skeidsmure van taal en kultuur of ras word summier verwerp; Blank of Swart of Bruin; Arabier of nie-Arabier; slegs een ding is van oorheersende belangrikheid: die graad van godvresendheid. Die besef om tot die beste Umma, die volk van gelowiges te behoort, bring 'n besondere sterk sendingbewussyn mee. Uit die Koran leer en glo die Moslem onwrikbaar dat die gehoorsaamheid aan die eise van Allah 'n waarborg bied vir die ewige behoud van die mens.

\section{2 'n Anti-Westerse emosie}

Die huidige herlewing van Islam neem sterk anti-Westerse aksente aan. Dit is in werklikheid nie iets nuuts nie. Dit was van die beginpunt van sy geskiedenis af met Islam so gewees.

Vra 'n mens na die redes hiervoor, word verskillende moontlikhede genoem. Een is dat die tipiese Westerse liberalisme lewensvreemd is aan Islam. Westerse liberalisme wat dié deel van die Weste is waarmee Islam voortdurend gekonfronteer word, het direk uit die Christendom gespruit. Liberalisme en verdraagsaamheid 
teenoor 'n enorme klomp idees, insigte en lewenstyle is immers tipies van die Christelike godsdiens. Dis slegs 'n godsdiens wat krities na alle wêreldse aktiwiteite en sukses kan kyk wat sy aanhangers kan toelaat om verskillende, selfs botsende politieke en sosiale filosofieë aan te hang.

Hierdie lewensuitkyk wat parallel loop met die evangelie is vir die Islam lewensvreemd. In hierdie opsig staan Islam baie nader aan die Ou-Testamentiese profete. Sommige kenners verstaan Islam die beste deur aan Mohammed te dink as 'n Ou-Testamentiese profeet wat ontydig gebore is. Geregtigheid is vir die Moslem deur die werke; geregtigheid wat bestaan uit die nougesette navolging van die voorskrifte van die Koran. Dit sluit in: aanbidding vyf keer per dag, 'n pelgrimsreis na Mekka, gawes vir die armes en om te vas gedurende die maand Ramadän. Islam volg die Koran op dieselfde wyse as wat Jode die dekaloog volg en gehoorsaam. Die vergelyking gaan verder. Mohammed het die Koran op bonatuurlike wyse ontvang, net soos Moses die Tien Gebooie op bonatuurlike wyse ontvang het.

Omdat geregtigheid vir die Moslem deur die werke is, is die Christelike visie dat gehoorsaamheid aan die wet wel noodsaaklik is, maar nie noodwendig voldoende voorwaarde vir verlossing nie, vir hom totaal onaanvaarbaar.

Die Islamitiese wetskode Shari'ah genoem, wat uit sowel die Koran as die oorlewering spruit, is die ruggraat van die wet van die Islamitiese staat. Vir die Moslem is daar geen onderskeid tussen menslike en Goddelike wet in Westerse sin nie. Die Islam is 'n nomokrasie, want dié Goddelike wet bevat 'n komplete beskrywing van die patroon vir ideale menslike gedrag; vanaf kwessies oor oorlog en vrede, huwelik en egskeiding, tot by tafelmaniere.

Dit verklaar vir ons ' $n$ inherente weerstand wat in Islam skuil teen enige vorm van liberalisering. Dit op sy beurt is vir alle moderne Westerse state onaanvaarbaar.

Die Koran is vir die Moslem letterlik die woord van Allah. Om dit op enige wyse te bevraagteken, is kettery. Islam was nog altyd verdraagsaam teenoor ander godsdienste binne sy gebied solank sodanige godsdienste nie politeïsties is nie. Maar net so onverdraagsaam was Islam ook nog altyd teen enige vorm van proselietmakery in sy midde. Die heilige oorlog word gevoer nie net teen die ongelowiges wat buite is nie, maar ook teen die afvalliges in eie midde.

Wie hom op enige wyse ten doel stel om die Islam of Islamitiese staat te liberaliseer, stel hom bloot aan aanvalle wat hulle direk op die Koran kan beroep.

Die Islamitiese wetskode gee ook volledige instruksies oor die regulering van die ekonomiese lewe. Woeker word verbied, maar privaat eiendom word toegelaat; so ook belastings om die lot van die 
armes te verlig. Dit word tans in die Islam geïnterpreteer as regverdiging vir die welsynstaat. Die Shari'ah se etiek is daarop gebou dat die rykes ryker word en die armes armer. Daaruit kan alle vorms van 'n sosialistiese ekonomie geregverdig word. Dit is egter direk strydig met die liberale kapitalisme.

Afgesien egter van godsdienstige faktore, kan veel van die huidige anti-Westerse stemminge by Islam uit staatkundige ontwikkelings verklaar word. Terwyl die Weste en die kerk nog in die greep van die Middeleeue verkeer het, het Islam vir eeue lank 'n geweldige ekspansie en hoogbloei beleef. Wat het die verval van Islam teweeggebring? Was dit alleen die Westerse opkoms sedert die Renaissance of was daar ook ander faktore soos inherente swakheid? Die idees van Aristoteles het immers via die Arabiere en veral Spanje die Weste ingekom en diepgaande invloed op bv. Thomas van Acquinas uitgeoefen. Daarom sê die Islam graag dat hulle die dokter was wat die pasiënt, die Weste, genees en aan die beskawing gehelp het, maar homself toe verwaarloos het.

In elke geval, die landing van Napoleon in Egipte in 1798 was die finale keerpunt. Daarna neem Westerse invloed geweldig toe totdat bykans die hele Islamitiese wêreld deur Westerse lande gedomineer word.

Wat die wêreld vandag van Islam ervaar, is ' $n$ geweldige regsradikale reaksie op eeue van Westerse oorheersing. Nadat die Weste sterk deur die Islam gestimuleer is, moet Islam eensklaps hoor dat hulle kultuur verguis word en dat hulle as onderontwikkeld afgeskryf word. So is baie Moslems vandag geneig om te redeneer. Sowel in Turkye as in Afghanistan en Iran was verbeeldingryke pogings aangewend om Islam terug te dwing en moondhede op Westerse patroon daar te stel. In al drie gevalle het hierdie pogings misluk. Vandag word beweer dat die Weste na sy industriële wetenskaplike en kulturele rewolusie die Derde Wêreld met sy 650 miljoen Moslems in groter armoede en ellende gelaat het as wat dit nog ooit geken het. Of dit 'n billike oordeel is, is te betwyfel.

Dis egter ' $n$ feit dat Islamitiese wetgeleerdes tans alle Westerse invloed radikaal afwys. Daar moet teruggekeer word na die Islam van vroeër, om die eie identiteit van voor die Westerse beïnvloeding terug te vind.

\section{Die Islam in Iran}

'n Mens kan die rewolusie in Iran nie begryp sonder kennis van die Shi-iete nie. Hulle is die nakomelinge van dié wat Ali na die dood van Mohammed teen Aboe Bakr ondersteun het. Hulle was van die begin af dus ' $n$ minderheid en is sodoende in die posisie van ' $n$ 
opposisie gedryf. Hul ideaal het ' $n$ lid van die familie van die profeet as kalief (plaasvervanger) op die troon sou kom, het nog nooit in vervulling gegaan nie. Ali was die neef en skoonseun van Mohammed. In die geskiedenis was die Shi'iete meermale vervolg deur die meerderheid Sunni-Moslems. Hulle is daarom basies suspisieus teen enige regeerder wat mag lyk op 'n uitbuiter of indringer. Hulle heg groot waarde aan die onderrig in die verborge, misterieuse en glo dat die twaalf Imams wat Mohammed opvolg, hierin besondere insig het. Hulle glo dat die twaalfde Imam, Mohammed al-Mahdi na die jaar 940 op verborge wyse bly leef het en aan die einde van die tyd sal terugkeer om die mensdom in 'n nuwe tydperk in te lei. Baie van wat in Iran gebeur het, word begryplik as 'n mens hoor dat toe die spanning begin hoog loop het, die gerug versprei is dat Khomeini die twaalfde Imam is. Dit het dié groot stimulus gegee aan die verdrywing van die Shah.

Hierdie stryd ten dode tussen die Ajatollah en die Shah speel hom af in die eeue-oue Persië, die land waar eers ook die aanbidders van Ahuramazda en Ariman, die gode van goed en kwaad, gewoon het. Die stryd tussen hierdie twee gode het altyd die lewe van mens en volk in Persië beheers. Ook in die heilige boeke van die Shi'ietise deel van die Islam is sprake van die worsteling tussen goed en kwaad. En hierdie stryd sal uitloop op die koms van die "Messiaanse" figuur, die twaalfde Imam.

En in hierdie stryd tussen goed en kwaad is van geen kompromis sprake nie. Wie godsdienstige fanatisme ken, weet dat in hierdie stryd alles, ook die lewe, edel en rustig op die spel geplaas word.

In Iran is vas geglo dat 'n kragtige boodskap, tot heil vir die volk van Iran en vir die hele wêreld, van die stryd teen die Shah uitgegaan het. Solank Amerika Iran probeer manipuleer of dreig, is dit 'n teken van hoe die mag van die kwaad aan die werk is. Die studente wat die gyselaars in Teheran aanhou, wil Amerika en die wêreld dwing om hulself rekenskap te gee van die bose metodes van die Westerse imperialisme. Alleen as die godsdienstige motiewe van die leiers in Iran in ag geneem word, sal daar'n oplossing kom.

Daar moet onthou word dat in Iran Westerse invloed maar' $n$ klein deeltjie van die bevolking ten goede gekom het. ' $n$ Klein groepie het gedeel in die welvaart en het aan die hele land 'n moderne Westerse vernissie gegee.

\section{Islam en Marxisme}

Oor die werklike houding van Islam teenoor Marxisme is al baie studeer en geskryf en steeds is daar nie helderheid nie. Normaalweg word gestel dat Islam onversoenbaar is met Marxisme. Tog is daar 
treffende ooreenkomste. Daar word geskryf van 'n man wat 'n parodie gemaak het op die Islamitiese geloofsbelydenis: daar is een God en Mohammed is sy profeet. Hy het daarvan gemaak: daar is geen God nie en Karl Marx is sy profeet. Het hierdie man miskien groter waarheid uitgespreek as wat hy vermoed het?

Beide Islam en Marxisme besit kanonieke tekste met spesifieke instuksies vir alle omstandighede en lewensterreine. Albei is fatalisties; die een met sy siening oor ' $n$ dialektiese meganisme van die geskiedenis; die ander met sy siening van 'n almagtige godheid. Albei streef na wêreldbeheersing deur hul eie geloofsbelydenisse. Nóg Islam nóg Marxisme is sku vir wapengeweld. Albei is basies aggressief. By die Islam spruit dit uit die siening dat die wêreld in twee gedeel is: die wêreld van vrede (Islam) en die wêreld van oorlog (ongelowiges). Geen permanente vrede is tussen hierdie twee moontlik nie. Alle vorms van vrede is net 'n tydelike truuk, net soos die Kommunistiese teorie van vreedsame naasbestaan.

Samewerking en oënskynlike versoening tussen Islam en Kommunisme kom tans voor in Libië, Sirië en Suid-Jemen. Daar is nie duidelikheid oor die mate waarin Moslems en Moslemleiers deur sekularisasie beïnvloed is nie. Indien toegegee sou moes word dat dit ook hier tot 'n groot mate van agnostisisme en onverskilligheid gelei het, sou dit 'n vrugbare teelaarde vir Kommunisme bied. Afgesien van die werklike verhouding, ken ons die Marxisme se vermoë om enige mag in te span vir eie doeleindes goed genoeg om onrustig te wees oor sy manipulering van Islam.

\section{Die kern van die kontrovers}

Islam het geen begrip of aanvoeling vir ' $n$ God van liefde of 'n mens wat verlossing nodig het nie. Islam konsentreer op die afhanklikheid van die heelal van een God.

Dit is tegelyk die groot krag en swakheid van Islam. Dis 'n aardse godsdiens. Die mens mag swak wees, maar hy het nie verlossing nodig nie. Solank hy sy kant van die saak met Allah reg hou, gesimboliseer deur die Ka'aba te Mekka, kan hy seker wees van die saligheid.

Islam glo nie dat die mens ' $n$ verlosser nodig het nie omdat hulle die Christelike leer oor die erfsonde verwerp. Die mens is nie as sondaar gebore nie en het daarom nie erfsonde nie.

Van die skerpste kritiek vanuit die Islam teen die Christendom is dat dit 'n godsdiens van die siel en die hemel is, sonder duidelike aanwysings oor hoe die maatskappy ingerig moet word. Daarby verdink Islam die Christene nie net van veelgodedom as dit om die Drie-eenheid gaan nie, maar ook van werklike afgodediens, materialisme, kapitalisme en militarisme. 
Die Christen se belydenis dat Christus ons enigste troos in lewe en dood is en dat naas Hom geen weg tot God is nie, is vir die Moslem 'n klap in die gesig. Jesus is 'n profeet soos alle ander, terwyl Mohammed die laaste, finale profeet, die seël van die profete is.

Daar is by Islam totale gebrek aan respek vir hierdie lewe. Respek vir die lewe mag daar nie wees nie, want dit sou die bereidheid om alles, ook die lewe self, vir Allah en gehoorsaamheid aan sy wil op die spel te plaas, kon verdoof.

Juis in die benadering tot lewe en dood kom van die mees diepgaande verskille tussen Islam en die evangelie aan die lig. Die mens moet leer om hierdie lewe as skoonskynende ydelheid te beskou. $\mathrm{Na}$ hierdie lewe word hy teruggebring tot Allah, òf om loon te ontvang, ò om die verskrikkings van die hel te ondergaan. Die Koran het 'n ontredderde uitkyk op dié lewe. Daar is geen koninkryk wat naby gekom het nie; geen versoenende sterwe aan die kruis nie; geen Paas- of Pinksterfees nie; geen vreugde en gemeenskap van heiliges nie. Dit ken slegs 'n herrysenis sonder opstanding, 'n dood waarvan die prikkel nie ontneem is nie.

\section{Redes vir Islam se suksesse}

Die staatsensus van 1970 toon dat daar op dié tydstip 270915 Moslems in Suid-Afrika was. By die skryf van hierdie artikel was die syfers van die 1980-sensus nog nie beskikbaar nie. Van die totale getal Moslems in 1970 was 945 Blankes, 8896 Swartes, 125987 Asiate en 134087 Kleurlinge. Veral die groot getal Kleurlinge wat Moslems is, is opvallend.

Dit leid geen twyfel nie dat die appèl van die Islam op die massas in baie lande so geweldig sterk is dat dit kan opsweep tot niks ontsiende fanatisme. Islam is veel meer as ' $n$ religie in die Westerse sin van die woord. Dit openbaar homself tans as ' $n$ omvattende kulturele rewolusie, gerig teen die opgedronge Westerse waardes en belange. Islam beheers elke aspek van die menslike lewe: geboorte, gesondheid, huwelik, gebed en geluk; staatkunde en ekonomie. Vir oud en jonk is die Koran 'n onfeilbare gids, ongeag die feit dat in baie Islamitiese lande tot 50 persent van die bevolking nog analfabeties is. Veral die gebeure in Iran het die besef opnuut laat ontwaak dat die Islam as geweldige inspirasiebron kan dien in die verwesenliking van ideale. Die huidige tendense in Islam was aanvanklik slegs ' $n$ verset teen uitbuiting en eksploitasie. Later het dit hom ook teen ander aspekte van modernisering begin rig. Bevrydingsbewegings verstaan en gebruik die emosies wat hier skuil. Daarom gebeur die eienaardige dat Islam almeer die stem word vir sowel antikommunistiese kruistogte as vir linkse bevrydingsbewegings. 
Die groot vraag wat 'n mens vandag ten opsigte van Islam boei, is: Kan hierdie godsdiens, na eeue se sluimering, werklik die uitdagings van ' $n$ moderne wêreld aandurf? Kan die profeet Mohammed dit maak in die twintigste eeu? Kan die Islamitiese wet werklik in 'n moderne beskaafde wêreld ten uitvoer gebring word? Na die rewolusionêre oorname van Khomeini is berig dat mense weens seksoortredings, soos prostitusie, homoseksualisme en owerspel gestenig word. Volgens Islamitiese tradisie word so 'n mens tot op borshoogte lewendig begrawe en daarna met klippe doodgegooi.

'n Mens moet natuurlik sê: In verskillende lande was die tyd eenvoudig ryp vir groot welslae deur Islam. Daarom klink die kreet al sterker op: nie kapitalisme of sosialisme nie, maar Islam.

Maar dit bly 'n vraag wat die konkretisering van 'n Islamitiese staat wesenlik beteken. Hoe moeilik dit is om die ekonomiese lewe in ooreenstemming met die voorskrifte van die Islamitiese wet te bring, blyk bv. uit die Islamitiese renteverbod.

Die roep om 'n Islamitiese herlewing kan miskien die beste begryp word as dit omskryf word as 'n sentiment wat Khomeini eenvoudig en kort onder woorde gebring het: Ons het die Koran; ons rewolusie is die Islam; ons is bereid om te sterf vir die Islam.

Ons sou dus kon twyfel oor die moontlikheid van Islam om hom by 'n moderne wêreld aan te pas. Ons sou kon twyfel of Islam bv. in Suid-Afrika in godsdienstige opsig werklike suksesse boekstaaf. Ons kan twyfel of die herlewing werklik diepgaande is. Maar dit sal ' $n$ groot flater wees om die gevaarlike impulse en emosies wat deur 'n gelade geloofsbelydenis, soos hierdie een van Khomeini, ingebed in die godsdiensfanatisme en gereedheid vir 'n heilige oorlog van mense wat aggressief ingestel is teen wat hulle as bose uitbuitery en imperialisme sien, te geringskat. Voeg daarby nog dat ons vandag oral in die wêreld by Islam 'n soepelheid en diplomasie aantref om, soos wat dit hom in 'n bepaalde land pas, in kombinasie met ideologieë van links en regs op tree, ook met die Marxisme. Hieroor kan en hoef ons vanuit die kerk allermins te hard te oordeel. Immers, ook die Christelike kerk en geloof toon 'n treurige geskiedenis van verbroedering met ideologieë deur die eeue.

Vra ons verder na die suksesse van Islam, moet ons daarop let dat Islam maklike, reglynige antwoorde verskaf op alle vrae. Islam eis bv. die uitspreek van die geloofsbelydenis sonder veel verdere begrip vir die implikasies daarvan. Dis nie net eenvoudig in die sin van: doen die wil van Allah en alles is reg nie; maar dis ook 'n geval dat die gebooie van Islam gematigd is. Enigeen kan daaraan voldoen. Daarom is daar geen behoefte aan ' $n$ middelaar nie. Dit was die blye boodskap van Mohammed: Niemand is van hierdie godsdiens uitgesluit nie; die kloof tussen Jode en Christene is geheel; die eenheid van Allah weerspieël hom in die eenheid van sy gemeente; 
Mohammed is die draer van die een openbaring. Daarom is die openbaringe van weleer, $\mathrm{Ou}$ en Nuwe Testament opgeneem in die Koran en omgesit in die leer van die eén God. Daarom is Jodedom en Christendom vir Islam afgedane sake, oorwonne standpunte. Om eensklaps te hoor dat hulle weer tot die Christelike evangelie bekeer moet word, is daarom vir die Moslem absurd!

Hierdie algemene godsdiens, Islam, is vir die Moslem die kroon van alle godsdiens omdat elke mens hier selfstandig 'n weg na Allah kan vind sodat niemand geestelike mag oor 'n ander kan hê nie. Omdat alle gelowiges voor Allah gelyk is, is Islam in wese demokraties. Vryheid en gelykheid word deur Islam gewaarborg. Dit was 'n geliefde uitspraak van Mohammed: Allah is my getuie dat ek glo dat die hele mensdom een familie is sonder voorkeur aan enige groep. Die Moslem glo vas dat, indien korrek geïnterpreteer, Islam die antwoord op alle hedendaagse probleme het.

Daarom wil Moslems terug na die oorspronklike Islam, dinamies en sterk soos hy in die begin was, onaangeraak deur ' $n$ verderflike Westerse kultuur.

Dat hierdie, in sekere sin eenvoudige godsdiens, met redelik reglynige antwoorde op moderne vrae; met geen rasseverskil nie; wat poligamie toelaat; wat buitendien soepel genoeg is om hom aan die kant van vryheidsbewegings te skaar; wat hom boonop resloos aan enige oorlog ten dode toe vir die eén God en gehoorsaamheid aan sy wil kan oorgee; wat veral ook fanaties genoeg is om die wapen op te neem teen ongelowiges en die mag van die Bose; dat hierdie godsdiens ook op die siel van Afrika groot impak kan hê, hoef ons nie te verbaas nie. Islam is trots daarop om deel van die Derde Wêreldmag te wees.

Voeg hierby nog die feit dat die Arabiese wêreld deur die opkoms van Israel en hulle stryd teen Israel eerder as ' $n$ hopeloos verdeelde as verenigde wêreld ontmasker is; voeg hierby ook nog dat die Westerse penetrasie sowel sosiale as politieke verskille in die Arabiese wêreld eerder verskerp as getemper het en sterker as ooit die Arabiese identiteit uitgedaag het; dan verstaan ' $n$ mens die sterkerwordende kreet in hierdie wêrelddeel: dit is in die Islamitiese geloof dat die enigste heil vir Arabië en die wêreld geleë is.

\section{Sending of dialoog}

Wat moet die kerk se houding en benadering tot Islam wees? Dat in die dialoogprogram van die Wêreldraad van Kerke en ook in die teologie van vele prominente teoloë nie net hernude belangstelling ten opsigte van Islam blyk nie, maar ook ' $n$ totale nuwe houding aan die lig tree, is glashelder.

In hierdie nuwe houding en benadering word daar nie meer ge- 
praat van die hardnekkige en halstarrige onbekeerlikheid van die Islam tot Jesus Christus as Verlosser nie. In hierdie teologiese denkwêreld is afgereken met die gedagte dat Moslems bekeer moet word tot Jesus Christus.

In hierdie kringe word graag en met reg verwys op die misverstande by kerk en teologie ten opsigte van Islam. Ons het vandag nog in baie opsigte 'n beeld van Islam wat uit die negende eeu stam. Aanvanklik is gemeen Islam is 'n Christelike sekte. Daarna het die beeld ontstaan van 'n meer fatalistiese godsdiens. In die Middeleeue is Mohammed beskou as tiran en wellusteling met allerlei psigiese afwykings. Die Islam is beskou as instrument van die Satan om die groei van die kerk teen te gaan.

Deur moderne navorsing en die Westerse Islamologie is hierdie beeld grotendeels oorwin, maar nog nie uitgewis nie. Vele spore daarvan, so word beweer, beïnvloed nog steeds die houding van die kerk teenoor Islam.

Daar word vandag gepleit vir 'n baie meer positiewe waardering van Islam. Die kerk moet sy idee dat Moslems bekeer moet word, laat vaar. Dis alleen die Gees van God wat die bekering werk. Daar word op gewys dat die enigste land waar Moslems ooit op groot skaal tot die evangelie van Christus bekeer is, Indonesië, dié groot getalle self tot die kerk gekom het en nie deur aggressiewe sending van die kerk se kant nie.

Juis in die verhouding tot die Islam het die mislukking van die sending gelei tot die soek van ander weë. Hierin het dialoog die mees geskikte geblyk. Maar telkens moet Christen-teoloë ervaar dat as hulle, in diens van 'n poging tot eerlike dialoog, die Christelike waarhede begin relativeer en praat van ' $n$ algemene godsdiens in die sin dat beide godsdienste 'n weg tot God bied, word hy in die rede geval met: daardie algemene godsdiens is juis die weg tot heil, gegrondves op die eén God, die eén openbaring en die eén wêreldwye gemeente. As Christene Moslems uitnooi om saam te bid tot die een God, is hierdie saambid vir Moslems 'n gebed tot Allah en beteken vir hom 'n toegewing van die kant van die Christen.

Dit is natuurlik waar dat dit die Gees van God is wat die bekering werk. Maar dit onthef nie die kerk van sy sendingopdrag nie.

Ons moet leer om Moslems nie met 'n meerderwaardige houding te benader nie. Ons moet leer om nie ons Westerse kultuur op die Moslemwêreld te wil afdruk nie, of in elk geval nie die indruk te laat dat dit is waarom dit gaan nie. Dit gaan nie daarom nie. Dit gaan om die verkondiging van Jesus Christus en sy evangelie. Die kerk moet erns maak daarmee om Islam reg en eerlik te verstaan en te ken. Dit is nodig dat misverstande wedersyds uitgeskakel word. Maar dit gaan in ons ontmoeting met Islam ook nie in die eerste plek om kensentrasie op al die misverstande nie. Dit gaan om die verkondi- 
ging van die ryk genade van God aan mense wat van nature, soos ons, in skuld en ellende dood is; mense wat hardnekkig bly klou aan 'n pligtegodsdiens en selfverlossingsleer; mense wat koppig bly klou aan die waan dat die mens goed is en nie verlossing nodig het nie, maar wat van hierdie optimisme oor die mens niks sien of beleef in die wêreld nie.

\section{Verlos uit dieptes van ellende}

Dat die enersyds gerieflike, andersyds half-primitiewe godsdiens van die Islam selfs in moderne Westerse lande een na die ander klaarblyklike sukses kan boekstaaf, bly aan die een kant ' $n$ aanduiding van die verval en agteruitgang van kerk en geloof in die Westerse wêreld en aan die ander kant 'n herinnering aan die geweldige geleenthede wat steeds voor die kerk ooplê.

Dit bly steeds ' $n$ brandende vraag: Hoe sou die geskiedenis verloop het as Mohammed en die Arabiere van sy tyd met die egte, lewende evangelie en geloof in Jesus Christus, te make gekry het?

Wat sien en beleef Islam vandag van die egte evangelie en die lewende geloof in Jesus Christus? Normaalweg veroorsaak aanraking met die Weste krisis. Dit lei tot ontreddering, ongeag tegniese en ekonomiese vooruitgang wat ook die resultaat van dié aanraking mag wees.

Ons moet die Koran lees en die Islam ontmoet, bestudeer en leer ken. Ons kan met Moslems dialoog voer of vir hulle preek. Waarop die kerk ook al besluit, dit moet eg, eerlik, opreg en in waarheid geskied.

As ons dit in opregtheid doen, is dit te betwyfel of ons ooit enige ander eerste en belangrikste gewaarwording kan hê as: Dank God vir die dieptes van donker en ellende, van wanhoop en selfverlossing deur goeie werke, waaruit $\mathrm{Hy}$ ons deur Jesus Christus gered het.

En wie dit ken, sal waarskynlik nie meer langer worstel met ingewikkelde vrae oor die korrekte en suksesvolle benadering tot die Moslem nie. Hy sal deur die Gees van God besiel wees met die drang en vaardigheid om met prediking, getuienis en lewe ook aan die Moslem te vertel van dié sterk en ryk genade van God wat alle verstand te bowe gaan, en wat lig en lewe en toekoms oopbreek waar die mens nog net donker en dood en ondergang kan vermoed.

Die probleemstelling oor die uniekheid van die Christendom is foutief. Nie die Christendom is uniek nie, maar Jesus Christus. En die uniekheid van Jesus Christus blyk nie uit 'n vergelyking met die ander godsdienste nie. Dit word verkondig deur die Bybel. En dis nie geleë in die maatskappy-kritiese invloed wat van hom uitgaan, 
soos Kuitert beweer nie. Jesus Christus is uniek as die groot Verlosser. Hy wys nie die weg nie. Hy is die Weg. Daarvan weet Islam nie. En dit is sy nood en ellende.

\section{Die volgende werke is by die opstel van hierdie stuk geraadpleeg}

1 Bleeker, C J, Wat gelooft de mensheid?, Bert Bakker/Daamen NV/Den Haag, 1961, p 139-172.

2 Capelle, M C, Moslems als buren, Oosterbaan \& Le Cointre B V - Goes - 1976.

3 Gaudeul, J M, Life in Islam: The great Muslim Feasts in Afer, 22 (3) Junie 1980, p 133-144.

4 Kohlbrugge, D J, Is Allah een nevenweg naast Christus? in Hervormd IVeekblad, 91 (4550), 12 Junie 1980, p 4.

5 Ling, Trevor, A History of Religion East and West, Macmillan and Co. Ltd. London, 1968, p 209-232, 286-303, 378-395.

6 Miller, Robert, Islam and the West in Theology, LXXXIII March 1980, p 119-122.

7 Mulder, D C, Dialoog met de Moslims, Rondom het Woord, 21 (4) Winter 79-80, p 75-80.

8 Naudé, J A, Die heropkoms van die Islam as politieke mag in Woord en Daad, 20 (216) Augustus 1980, p 5-7.

9 Oosthuizen, G C, Die Godsdiente van die wêreld, NG Kerkboekhandel Transvaal, 1977, p 43-116, 329-341.

10 Redaktionsartikel, Mohammeds Feuer und Schwert in Evangelische Kommentare, 13 (2) Feb 1980, p 67-69.

11 Ringgren, Helmer and Ström, Ake V, Religions of Mankind Today and Yesterday, edited by J C G Greig, translated by Niels J Jensen, Fortress Press Philadelphia, p 175-206.

12 Schuman, L O, De Arabieren, Cultuurgeschiedenis van de Arabische wêreld, W de Haan, NV, 1960.

13 Van der Linden, J, De vergeten achtergrond van de gijzeling in Iran in Centraal Weekblad, 28 (37), 10 September 1980, p 4.

14 Van Leeuwen, Arend Th., Christianity in World History, Edinburgh House Press, London, 1964, p 182-209.

15 Van Leeuwen, A Th., Het Christendom en de Islam, Oriëntatie-reeks III, NV Uitgeversmaatschappij, Lochem, 1961.

16 Von Sicard, Siqvard, Islam in Afrika, in Evangelische Kommentare, 13 (6), Junie 1980, p 337-338.

17 Wessels, A, De Renaissance van de Islam in Rondom het Woord, 21 (4) Winter 1979-1980, p 69-74.

18 Wessels, A; Mulder, D C en Askari, H Islam-Gisteren en Morgen in Rondom het Woord, 20 (3) Sept 1978, p 1-63.

19 World Council of Churches, Christians meeting Muslims, W C C Papers on Ten Years of Christian-Muslim Dialogue, World Council of Churches, 150 route de Ferney 1211, Geneva 20, Switzerland. 